\title{
Akut coronaria szindrómán átesett thrombocytopeniás betegek thrombocytaaggregáció-gátló gyógyszeres kezelése
}

\author{
Fehér Ágnes dr. ${ }^{1}$ - Istenes Ildikó dr. ${ }^{1}$ - Weisinger Júlia dr. ${ }^{1}$ \\ Király Péter dr. ${ }^{1}$ - Rakonczai Anna dr. ${ }^{1}$ - Tárkányi Ilona dr. ${ }^{1}$ \\ Kárpáti Ágnes dr. ${ }^{1}$ - Hanna Eid dr. ${ }^{1}$ - Megyeri Andrea dr. ${ }^{1}$ \\ Nagy Zsolt dr. ${ }^{1}$ - Demeter Judit dr. ${ }^{1}$ - Becker Dávid dr. ${ }^{2}$
}

\footnotetext{
${ }^{1}$ Semmelweis Egyetem, Általános Orvostudományi Kar, Belgyógyászati és Onkológiai Klinika, Budapest ${ }^{2}$ Semmelweis Egyetem, Általános Orvostudományi Kar, Városmajori Szív- és Érgyógyászati Klinika, Budapest
}

\begin{abstract}
Az akut coronaria szindrómán (ACS) átesett betegek kezelésének alappillére a kettős (aszpirin + klopidogrél ) thrombocytaaggregáció-gátló kezelés. Az immunthrombocytopeniás purpurás (ITP-s) betegek - és különösen azok, akik refrakter ITP miatt thrombopoetinanalóg kezelésben részesülnek - külön elbírálást igényelnek. 50-100 G/1 thrombocytaszám közötti és vérzéses szövődménnyel nem rendelkező ACS-s betegeken a gyógyszerkibocsátó stent beültetését követően kettős thrombocytaaggregáció-gátló kezelést csak 1 hónapig kell alkalmazni (ez az időtartam átlagos vérzéses rizikójú betegeken l év), majd klopidogrél-monoterápia javasolt. Munkánk során a 2015. január l. és 2020. október 1. között a Semmelweis Egyetem I. Belgyógyászati Klinikáján kezelt ITP-s betegek körében vizsgáltuk az ACS előfordulását és lefolyását. Klinikánkon az elmúlt 5 évben gondozott, 168 ITP-s beteg közül 3 beteg esetében alakult ki ACS. A refrakter ITP kezelésének részeként mind a 3 beteg thrombopoetinanalóg - (2 beteg romiplosztim-, 1 beteg eltrombopág-) kezelésben részesült. A 3 ITP-s betegünk egyikénél sem alakult ki vérzéses szövődmény a thrombopoetinanalóg-kezelés és a thrombocytaaggregáció-gátlás mellett. Első betegünk esetében 5 év alatt három alkalommal alakult ki ACS (egy ízben fémstentet és két alkalommal gyógyszerkibocsátó stentet kapott). A második betegnél két alkalommal (l év különbséggel), a harmadik betegnél egy esetben történt gyógyszerkibocsátó stent beültetése. ITP és ACS együttes fennállása esetén az akut és a hosszú távú gyógyszeres kezelés egyéni mérlegelést igényel. Ezen speciális betegcsoport számára a kezelési irányelv kidolgozása megfontolandó.
\end{abstract}

Orv Hetil. 2021; 162(33): 1335-1340.

Kulcsszavak: immunthrombocytopenia, akut coronaria szindróma, kettős thrombocytaaggregáció-gátlás, thrombopoetinanalóg-kezelés

\section{Management of antiplatelet therapy in acute coronary syndrome patients with thrombocytopenia}

Dual antiplatelet therapy (DAPT) consisting of aspirin and clopidogrel is essential in the treatment of acute coronary syndrome (ACS). Immune thrombocytopenic purpura (ITP) patients - and especially those receiving thrombopoietin analog (TPO) treatment - deserve special attention. In ACS patients with platelet counts between $50 \mathrm{G} / \mathrm{L}$ and $100 \mathrm{G} / \mathrm{L}$ and no bleeding symptoms, DAPT is indicated for 1 month after the placement of new generation drugeluting stents (the length of treatment is 1 year in the case of patients with average bleeding risk) followed by clopidogrel monotherapy. In patients with average bleeding risk, DAPT is recommended for 1 year after the ACS. Our aim was to investigate the incidence and outcome of ACS in ITP patients, who were treated in our clinic between lst January 2015 and lst October 2020. Out of 168 patients treated for ITP, 3 patients suffered from ACS in the last 5 years. These patients received TPO treatment ( 2 patients subcutan romiplostim, 1 patient oral eltrombopag). None of these ITP patients treated with DAPT and with TPO analog suffered from bleeding complications. 1 patient developed ACS three times within the last 5 years (he received bare-metal stent once and drug-eluting stent twice). 
Drug-eluting stent was placed once in the third, and twice (with 1 year difference) in the second patient. Acute and long-term medication of patients suffering from both ITP and ACS is a challenging task and needs individual evaluation. Establishment of treatment guidelines for this special group is warranted.

Keywords: immune thrombocytopenia, acute coronary syndrome, dual antiplatelet therapy, thrombopoietin analog treatment

Fehér Á, Istenes I, Weisinger J, Király P, Rakonczai A, Tárkányi I, Kárpáti Á, Eid H, Megyeri A, Nagy Zs, Demeter J, Becker D. [Management of antiplatelet therapy in acute coronary syndrome patients with thrombocytopenia]. Orv Hetil. 2021; 162(33): 1335-1340.

(Beérkezett: 2020. december 29.; elfogadva: 2021. január 29.)

\section{Rövidítések}

$\mathrm{ACE}=$ (angiotensin-converting enzyme) angiotenzinkonvertáló enzim; ACS = (acute coronary syndrome) akut coronaria szindróma; $\mathrm{APT}=$ (antiplatelet therapy) thrombocytaaggregáció-gátló kezelés; $\mathrm{BMS}=$ (bare metal stent) fémhálós stent; $\mathrm{CMV}=$ cytomegalovirus; $\mathrm{COX}=$ ciklooxigenáz; $\mathrm{CVID}=$ (common variable immunodeficiency) közönséges variábilis immundeficientia; DAPT $=$ (dual antiplatelet therapy) kettôs thrombocytaaggregáció-gátló kezelés; DES = (drug-eluting stent) gyógyszerkibocsátó stent; DIC = disszeminált intravascularis coagulopathia; EDTA $=$ (ethylenediaminetetraacetic acid) etilén-diamin-tetraecetsav; $\mathrm{HCV}=$ hepatitis $\mathrm{C}$-vírus; HIV $=$ (human immunodeficiency virus) emberi immunhiányt elöidézô vírus; HUS = haemolyticus uraemiás szindróma; ITP = immunthrombocytopeniás purpura; IVIG = intravénás immunglobulin; LAD = (left anterior descending artery) a bal coronaria elülső leszálló ága; NSTEMI = (non-ST-elevation myocardial infarction) nem ST-elevációval járó myocardialis infarctus; $\mathrm{PCI}=$ percutan coronariaintervenció $; \mathrm{PPI}=($ proton pump inhibitor $)$ protonpumpagátló; RCA $=$ (right coronary artery) jobb koszorúér; SCORE $=$ (systemic coronary risk estimation) fatális szív- és érrendszeri esemény; SLE = szisztémás lupus erythematosus; STEMI (ST-elevation myocardial infarction) ST-elevációval járó myocardialis infarctus; TPO = thrombopoetin; TTP $=$ thromboticus thrombocytopeniás purpura

A thrombocyták a csontvelőben megakaryocytákból képződnek thrombopoetin (TPO) hatására [1]. A TPO felfedezésében, élettani hatásának megismerésében kiemelendő a TPO névadójának, Kelemen Endre profeszszornak a munkássága [2], aki 1958-ban publikálta az Acta Haematologicában a munkacsoportjával elért vizsgálati eredményeit, de a TPO rekombináns technikával történő előállítása csak 36 évvel később, 1994-ben valósult meg $[3,4]$. Ez a kutatási folyamat vezetett oda, hogy a szteroidkezeléssel szemben refrakter immunthrombocytopeniás purpurában (ITP) szenvedő betegeken végül a TPO-receptor-serkentő kezelés a felnőtt ITP-s betegek esetében a mindennapi rutin része lett [2]. A gyermekkori refrakter ITP kezelésében is szerepet játszik mindkét készítmény, a romiplosztim és az eltrombopág. A vezető gyermekhematológusok állásfoglalása szerint bár a két, jelenleg rendelkezésre álló thrombocy- tastimuláló készítmény között nincs lényeges terápiás hatékonyságbeli különbség, a gyermekek számára kényelmesebb lehet a per os adagolás (eltrombopág), mint a hetente adott subcutan injekció (romiplosztim) [5]. Gyermekkorban ez a két készítmény 'off-label' (indikáción túli használatra vonatkozó ) engedély birtokában alkalmazható, míg felnőttek esetében az alkalmazási előiratnak megfelelő indikációban a kijelölt hematológiai centrumokhoz kötött a kezelés lehetósége.

A vérlemezkék fó élettani szerepe a véralvadás szabályozásában van, de emellett szerepet kapnak az immunés a gyulladásos folyamatok regulálásában is [6]. A normál-thrombocytatartomány 150-450 G/1 közötti; enyhe thrombocytopenia esetében a vérlemezkeszám 100-150 G/1, mérsékelt esetben 50-100 G/1, míg súlyos thrombocytopenia fennállása esetén a vérlemezkeszám 50 G/l alatt mérhető [7].

A thrombocytopenia kialakulását tekintve számos oki tényezőt különböztetünk meg. A kivizsgálás során az első lépés az EDTA indukálta pseudothrombocytopenia kizárása. A valódi thrombocytopenia oka lehet többek között a fokozott sequestratio, a csontvelő elégtelen múködése vagy a vérlemezkék fokozott pusztulása [8]. Egy kanadai tanulmány szerint az intenzív ellátást igénylő betegek $40-50 \%$-ában alacsonyabb a vérlemezkeszám [9], és ezen esetek döntô többségére az akut megjelenés jellemző. A hospitalizációasszociált akut thrombocytopenia okai között szerepelhet mechanikai destrukció (intraaorticus ballonpumpa, cardiopulmonalis bypass), másrészt a szepszishez/infekcióhoz, transzfúzióhoz (poszttranszfúziós thrombocytopenia), terhességhez (eclampsia) társuló thrombocytopeniák. A gyógyszer indukálta thrombocytopeniák közül kiemelendő a heparin indukálta thrombocytopenia, de emellett többek között a szalicilátok, penicillinek, amiodaron, indometacin, aminofenazon, fenilbutazon, klozapin, hidantoinszármazékok egyaránt kiválthatnak thrombocytopeniát. Mindezek mellett természetesen a TTP, a HUS, a DIC és a közleményünk fő irányvonalát adó ITP szerepe is kiemelendő [10].

Az ITP az etiológiáját tekintve lehet primer (idiopathiás) és szekunder (például infekciókhoz társuló [Heli- 
cobacter pylori, HCV, HIV, CMV], CVID, Evans-szindróma, antifoszfolipid-szindróma, SLE társjelensége, gyógyszer által indukált ITP, tumorasszociált ITP) [11]. ITP esetében egyrészt autoantitestek termelődnek a thrombocyták (többek között glikoprotein IIb/IIIa, glikoprotein Ib/IX, glikoprotein Ia/IIIa receptor ellenes antitesteket is kimutattak), illetve megakaryocyták felszínén található antigének ellen, másrészt bizonyos esetekben csökken a vérlemezkék termelődése is [12]. Míg korábban az első mechanizmust, az ellenanyagok hatására történő pusztulást tartották döntőnek, addig a TPOszintek ismeretében ma már a thrombopoesis relatív elégtelenségét is hangsúlyozzuk. Mindez összességében a thrombocytaszám jelentős csökkenését okozhatja, ami akár súlyos, életet veszélyeztető vérzések kialakulásához vezethet [13].

Általánosságban igaz, hogy a vérlemezkék számának csökkenése arányos a vérzéses szövődmények súlyosságával, habár paradox módon egyes esetekben ITP-ben mind a vénás, mind az artériás thrombosis kockázata fokozott [14]. Ennek mechanizmusa nem tisztázott, de egyes betegeknél antifoszfolipid-antitesteket mutattak $\mathrm{ki}$, melyek ismerten fokozzák a thrombosisrizikót [11]. Az ITP-s, illetve egyéb okból thrombocytopeniás betegek körében előforduló ischaemiás történések esetén (például stroke, akut myocardialis infarctus ) korlátozott terápiás lehetőségek állnak rendelkezésünkre, többek között a thrombolysis kontraindikációi között is szerepel a thrombocytopenia (<100 G/1) [15]. Az ACS-ban szenvedő betegeknél ellenjavallt a percutan coronariaintervenció (PCI) $50 \mathrm{G} / 1$ vérlemezkeszám alatt, pedig az ACS-betegek 5\%-ában figyelhetünk meg gravis thrombocytopeniát [16].

Az ACS-n átesett betegek kezelésének alappillérét a kettős thrombocytaaggregáció-gátló kezelés (dual antiplatelet therapy - DAPT) képezi, mely ciklooxigenáz (COX)-1-gátlót és P2Y12-receptor-antagonistát tartalmaz. A két gyógyszer kombinációja jelentősen csökkenti a stentthrombosis kockázatát [17]. A thrombocytopeniás, ACS-n átesett betegek gyógyszeres kezelése ugyanakkor nem kézenfekvő, hiszen egy tanulmány szerint az abszolút thrombocytaszám 10\%-os csökkenése már szignifikánsan növeli a vérzéses kockázatot és a mortalitást [16].

Thrombocytopeniás/ITP-s, ACS-n átesett betegek thrombocytaaggregáció-gátló kezelését (APT) illetôen mind a mai napig nincs egyértelmú ajánlás. Esetismertetésekben, illetve összefoglaló közleményekben olvashatunk javaslatokat a betegellátás tekintetében. Jelen munkánkban a Semmelweis Egyetem Belgyógyászati és Onkológiai Klinikáján gondozott ITP-s, ACS-n átesett betegeinket szeretnénk bemutatni, majd röviden összefoglaljuk a jelenleg elfogadott kezelési javaslatokat.

\section{Módszerek}

A Semmelweis Egyetem Belgyógyászati és Onkológiai Klinikáján (2015. január 1-tôl áttekintve az adatokat) 168, ITP-s beteg áll gondozás alatt. Összesen 3 beteg esetében alakult ki ACS, az egyik betegnél ismétlődően. Mind a 3 beteg krónikus ITP-ben szenved, vérlemezkeszámuk TPO-analóg-kezelés mellett stabilizálódott: 2 beteg romiplosztimot, 1 beteg eltrombopágkezelést kap. $\mathrm{Az}$ eseteket az alábbiakban ismertetjük.

\section{Eredmények - esetismertetések}

\section{Elsö eset}

Az 1971-es születésű obes, nagy cardiovascularis kockázatú (SCORE: 5, évtizedek óta dohányzik, rendszeresen szedett gyógyszerei között ACE-gátló szerepelt) férfi betegünknél 2009-ben testszerte jelentkező petechiák, haematemesis hátterében $10 \mathrm{G} / 1$ alatti thrombocytaszint állt. A thrombocytaszám akkor vitális indikációval adott thrombocytatranszfúzió, szteroid-lökésterápia, majd intravénás immunglobulin (IVIG) adása mellett átmenetileg normalizálódott ( $186 \mathrm{G} / \mathrm{l})$. Az elvégzett csontvelöbiopsziás vizsgálat alátámasztotta az ITP fennállását. A betegnél az enyhe légúti infekciókat követő, szteroidlökésterápiára gyógyuló relapsusok mellett 2012-ben 2 alkalommal is életet veszélyeztetô gastrointestinalis vérzés alakult ki gravis thrombocytopenia miatt $(<10 \mathrm{G} / \mathrm{l})$. A beteg a javasolt splenectomiát elutasította, ezért TPOanalóg romiplosztim adását kezdtük meg, mely mellett a beteg thrombocytaszáma 100 G/1 körüli értékeken mozgott.

2015 márciusában a betegen petechiák, purpurák jelentek meg, thrombocytaszáma $6 \mathrm{G} / \mathrm{l}$-nek bizonyult, ezért szteroid-lökésterápia indult. Ezt követően 2 nappal - még mindig < $10 \mathrm{G} / \mathrm{l}$ vérlemezkeszám mellett - anterior STEMI alakult ki. A szteroid-lökésterápia és a romiplosztimkezelés folytatásával a thrombocytaszám 2 nap után elérte a 40 G/l-t, mely mellett a perzisztáló mellkasi fájdalomra tekintettel (egyéni mérlegelés alapján a javasolt $50 \mathrm{G} / 1$ thrombocytaszám alatt) megtörtént a coronarographia (LAD-BMS stent beültetése), és aszpirin- és klopidogrélkezelés indult. Majd 2015 júniusában a jelzett retrosternalis fájdalom hátterében a beültetett LAD-stent diffúz instent restenosisa állt. $80 \mathrm{G} / 1$ vérlemezkeszám mellett LAD-DES stent beültetése történt. Tekintettel az ismétlődő ACS-re, a thrombophilia irányvonalában végzett laborvizsgálatok lupus-antikoaguláns jelenlétét mutatták ki; ez antifoszfolipid-szindróma fennállását igazolta, ezért a beteg hosszabb ideig, 1 helyett 9 hónapig részesült DAPT-ben, amelyet tartós klopidogrél-monoterápia követett.

2017 áprilisában a betegnél kiújuló mellkasi panaszok miatt ismét coronarographia történt, mely a bal corona- 
ria obtuse marginalis ágának occlusióját igazolta: DES stent beültetése után a betegnél újfent DAPT indult. A beteg a subcutan romiplosztimot rendszeresen alkalmazta, az infarktus kialakulásakor thrombocytaszáma 118 $\mathrm{G} / 1$ volt. Ezt követően a betegnél ACS nem ismétlődött, thrombocytaszáma romiplosztim adása mellett stabil maradt (80-120 G/1), a DAPT a kardiológiai irányelveknek megfelelően zajlott [18].

\section{Második eset}

Az 1952-es születésû nőbetegnél 1993-ban diagnosztizáltak krónikus ITP-t. Mivel a beteg a szteroid mellékhatásait nem tolerálta, splenectomia történt még ugyanabban az évben. Átmeneti javulás után ismételten thrombocytopenia alakult ki, ezért 1993-ban azatioprinkezelés indult, melyet évekig tartó remisszió követett. A betegnél 2010-ben az ITP relapsusa jelentkezett, illetve szteroidintolerancia miatt a betegnél maximális dózisú $(10 \mu \mathrm{g} / \mathrm{ttkg})$ romiplosztimkezelés indult, mely mellett thrombocytaszáma tartósan 80-120 G/1 között mozgott. Infekciók esetén a beteg vérlemezkeszáma drámaian csökkent, ilyenkor átmeneti szteroidkezelés mellett - a kiváltó noxa megszúnése után - a thrombocytaszám ismételten emelkedett.

2019 szeptemberében a betegnél 95 G/1 thrombocytaszám mellett NSTEMI alakult ki, mely miatt LAD-DES stent beültetése történt, majd DAPT indult. 2020 szeptemberében effortangina miatt ismételt coronarographia történt, melynek során RCA-PCI-re és DES stent implantációjára került sor a DAPT indítása mellett (jelenleg is enyhe fokú thrombocytopenia áll fenn a maximális dózisú romiplosztim mellett). A beteg közepes cardiovascularis rizikófaktorú csoportba tartozott (SCORE: 3, a dohányzásról 40 éve leszokott, előtte 10 szál/nap 10 évig), az ACS-t megelőzően már primer prevencióként sztatint, ACE-gátlót szedett.

\section{Harmadik eset}

Az 1964-ben született férfi betegnél szteroidra rezisztens ITP miatt a diagnózis évében, 1994-ben splenectomia történt, majd 2012-ben az ITP relapsusa miatt per os eltrombopágkezelés indult, mely mellett a beteg thrombocytaszáma a normáltartományban mozgott. 2019 szeptemberében a bal karba sugárzó, retrosternalis fájdalom hátterében NSTEMI igazolódott (thrombocytaszáma ekkor $220 \mathrm{G} / 1$ volt). DES stent beültetése történt, majd DAPT indult a nem thrombocytopeniás betegekre vonatkozó kardiológiai irányelveknek megfelelően [18]. A beteg cardiovascularis szempontból a közepes kockázati csoportba tartozott (SCORE: 3, rendszeresen szedett gyógyszerei között ACE-gátló szerepelt, nem dohányzott). A betegek klinikai adatait az 1. táblázat tartalmazza.

\section{Megbeszélés}

Számos klinikai tanulmány szól az ACS-n átesett, thrombocytopeniás betegek morbiditásának, mortalitásának vizsgálatáról. Nagy esetszámú (10 603 fös), enyhén thrombocytopeniás betegek adatait elemző vizsgálatokban a thrombocytopenia önmagában is, független tényezőként növelte a mortalitást ACS kialakulása esetén. Eredményeik szerint rövid távon (30 napon belül) a vérzéses rizikó nem növekedett [19], míg egy másik nagy esetszámú vizsgálatban (36 182 beteg) igazolták, hogy a vérlemezkeszám 10\%-os csökkenése (a normáltartományhoz képest) jelentősen fokozza mind a vérzés kockázatát, mind a mortalitást [16]. A vérzés kockázatának becslésekor természetesen nem szabad figyelmen kívül hagyni a társbetegségeket, illetve a thrombocytopenia kiváltó okát sem (például krónikus májbetegség).

A mérsékelt/súlyos thrombocytopeniás betegekben fellépő ACS APT-jét illetôen a mai napig nincs bizonyítékokon alapuló adat, pedig a kórképek gyógyszeres ke-

1. táblázat | Összefoglaló táblázat a klinikán kezelt és a közleményben részletezett esetekről

\begin{tabular}{|c|c|c|c|c|}
\hline Eset & Születési idő / nem & Az ITP-diagnózis ideje / az ITP kezelése & Az ACS ideje / thrombocytaszám & Kezelés \\
\hline 1. & $\begin{array}{l}1971 \\
\hat{\delta}\end{array}$ & $\begin{array}{l}2009 \\
\text { GC, IVIG, romiplosztim }\end{array}$ & $\begin{array}{l}\text { 2015: }<10 \mathrm{G} / 1 \\
\text { (PCI: } 40 \mathrm{G} / 1) \\
\text { 2015: } 80 \mathrm{G} / 1 \\
2017: 118 \mathrm{G} / 1\end{array}$ & $\begin{array}{l}\text { LAD-BMS stent, DAPT } \\
\text { LAD-DES restent, DAPT } \\
\text { OM-DES stent, DAPT }\end{array}$ \\
\hline 2. & $\begin{array}{l}1952 \\
+\end{array}$ & $\begin{array}{l}1993 \\
\text { GC, splenectomia } \\
\text { romiplosztim }\end{array}$ & $\begin{array}{l}\text { 2019: } 95 \mathrm{G} / 1 \\
\text { 2020: } 160 \mathrm{G} / 1\end{array}$ & $\begin{array}{l}\text { LAD-DES stent, DAPT } \\
\text { RCA-DES stent, DAPT }\end{array}$ \\
\hline 3. & $\begin{array}{l}1964 \\
0\end{array}$ & $\begin{array}{l}1994 \\
\text { GC, splenectomia } \\
\text { eltrombopág }\end{array}$ & 2019: $220 \mathrm{G} / 1$ & DES stent, DAPT \\
\hline
\end{tabular}

ACS = akut coronaria szindróma; BMS = fémhálós stent; DAPT = kettős thrombocytaaggregáció-gátló kezelés; DES = gyógyszerkibocsátó stent; GC = glükokortikoid; ITP = immunthrombocytopeniás purpura; IVIG = intravénás immunglobulin; LAD = a bal coronaria elülső leszálló ága; $\mathrm{OM}=$ obtuse marginalis; $\mathrm{PCI}=$ percutan coronariaintervenció; $\mathrm{RCA}$ = jobb koszorúér 
zelési nehézsége évek óta ismert [16, 20]. A vérzéses rizikó csökkentésére javasolják, hogy kerüljük az NSAID, glikoprotein IIb/IIIa gyógyszerek alkalmazását, valamint kontraindikáció esetleges megjelenéséig alkalmazzunk protonpumpagátlókat (PPI). A COXl-gátló aszpirin, ha feltétlenül szükséges alkalmazni, csakis kis dózisban adható, valamint kerülni kell a hármas kombinációjú antikoagulálást. Abban az esetben, amikor PCI kivitelezhető, a radialis behatolást kell előtérbe helyezni a femoralissal szemben, emellett a (második vagy újgenerációs) DES stentek előnyösebbnek bizonyultak a BMS stentekhez képest [20].

Általánosságban elmondható, hogy a közlemények nem javasolják PCI elvégzését abban az esetben, ha a vérlemezkeszám $50 \mathrm{G} / 1$ alatti, illetve természetesen akut vérzés fennállása esetén sem [21]. Saját eseteinkben is törekedtünk először a thrombocytaszámot $50 \mathrm{G} / \mathrm{l}$ fölé emelni, majd azt követően történt a coronarographia, illetve a stentbeültetés. Gravis thrombocytopenia/vérzés esetén egyes közlemények szteroid/IVIG előkezelést is javasolnak [22].

Ha a vérlemezkeszám több mint $50 \mathrm{G} / 1$, és nincs vérzéses tünet, a PCI kivitelezhető. Ebben az esetben a stent beültetését követően 1 hónapig javasolt a DAPT (fentebb idéztük Wang és mtsai 2009. évi publikációját: egyes tanulmányok azt igazolták, hogy enyhe thrombocytopenia esetén a DAPT utáni 30 napon belül sem a major, sem a minor vérzések aránya nem nő szignifikánsan), melyet a P2Y12-receptor-antagonista klopidogrélmonoterápia követ PPI adása mellett. Abban az esetben, amikor PCI nem kivitelezhető, klopidogrél-monoterápia javasolt PPI-védelemben [19]. Igazolták, hogy klopidogrél alkalmazása esetén kisebb a vérzéses szövődmények kialakulása, szemben a praszugrél és a tikagrelor tartós alkalmazásával [23], viszont az utóbbi két gyógyszer alkalmazása mellett a stentthrombosis kockázata kisebb [17]. Magyarországon finanszírozási okok miatt a klopidogrél alkalmazása terjedt el a DAPT részeként.

Természetesen ezen betegek esetében az ACS rövid/ hosszú távú megoldása mellett a krónikus ITP kezelése is egyéni mérlegelést igényel. Szteroidrezisztencia, illetve a tartós szteroidkezelés mellett megjelent jelentős mellékhatások esetén alternatív kezelést kell választanunk. Splenectomia kontraindikációja/hatástalansága esetén a TPOmimetikumokkal (subcutan romiplosztim - TPO-analóg fúziós fehérje, oralis eltrombopág - kis molekulaméretű TPO-receptor-agonista) hosszú távon viszonylag stabil thrombocytaszámot lehet elérni az esetek túlnyomó többségében thromboticus szövődmények megjelenése nélkül [24]. Saját eseteinkben is hosszú távú kezelésként a TPOmimetikumok adását részesítettük előnyben.

\section{Következtetés}

Összességében elmondható, hogy ACS esetén 50 G/1 alatti thrombocytaszámnál egyéni mérlegelés alapján, a kockázatok/szövődmények tudatában merülhet fel az invazív beavatkozás szükségessége. Alapvetően minden ITP-s betegnél törekedni kell a tartósan 50 G/1 feletti thrombocytaszám elérésére, mely mellett rövid ideig DAPT, majd mono-APT javasolt. Rendszeres orvosi kontroll alatt lévő betegnél, akinél a vérlemezkeszám tartósan 100 G/1 feletti értéken stagnál, a kardiológiai irányelveknek megfelelő APT megadható [18].

Mindemellett hangsúlyozzuk, hogy ismétlődő artériás thrombosis elófordulásakor, fóleg extrém alacsony thrombocytaszám esetén, ki kell zárni/meg kell erősíteni az antifoszfolipid-szindróma diagnózisát. Antifoszfolipid-szindróma fennállásakor élethosszig tartó antikoagulálás (vénás thrombosis esetén) vagy APT indokolt (artériás thrombosis esetén) [25].

Ezen betegek ellátása során elengedhetetlen a kardiológiai-hematológiai szoros szakorvosi kooperáció. Jelenleg nem áll rendelkezésre szakmai irányelv thrombocytopeniás, ACS-n átesett betegek kezelésére, csak egyes közleményekben (döntően esetismertetésekben) olvashatunk ennek a betegcsoportnak az ellátására vonatkozó ajánlásokat. Eseteink bemutatásaival és az irodalomban ismert közlemények összefoglalásával az eddigi ismereteket szeretnénk kiegészíteni.

Anyagi támogatás: A kapcsolódó kutatómunka anyagi támogatásban nem részesült.

Szerzôi munkamegosztás: F. Á., I. I., W. J., K. P., R. A., T. I., K. Á., H. E., M. A., N. Zs., D. J. diagnosztizálták, illetve gondozták a betegeket. F. Á. gyújtötte össze az adatokat. B. D. és munkacsoportja végezte a betegeken az invazív beavatkozásokat. A közlemény koncepcióját D. J. és B. D. dolgozta ki. A cikk végleges változatát valamennyi szerző elolvasta és jóváhagyta.

Érdekeltségek: A szerzőknek nincsenek érdekeltségeik.

\section{Irodalom}

[1] Kaushansky K. Thrombopoietin: the primary regulator of platelet production. Blood 1995; 86: 419-431.

[2] Fekete S. Thrombopoietin and thrombopoietin mimetics - In memoriam Endre Kelemen. [Thrombopoetin és thrombopoetin-mimetikumok - In memoriam Kelemen Endre]. Hematológia 2008; 41: 123-126. [Hungarian]

[3] Kelemen E. Specific thrombopoietin cloned and sequenced with personal retrospect and clinical prospects. Leukemia 1995; 9: $1-2$.

[4] Kelemen E, Cserháti I, Tanos B. Demostration and some properties of human thrombopoietin in thrombocythaemic sera. Acta Haematol. 1958; 20: 350-355.

[5] Kovacs G, Kiss Cs. Novelties in the treatment of pediatric immune thrombocytopenia - 2017. [Újdonságok a gyermekkori immunthrombocytopenia kezelésében - 2017.] Orv Hetil. 2017; 158: 1891-1896. [Hungarian]

[6] Franco AT, Corken A, Ware J. Platelets at the interface of thrombosis, inflammation, and cancer. Blood 2015; 126: 582-588.

[7] Khammissa RA, Fourie J, Masilana A, et al. Oral manifestations of thrombocytopaenia. Saudi Dent J. 2018; 30: 19-25. 
[8] Lee EJ, Lee AI. Thrombocytopenia. Prim Care 2016; 43: 543557.

[9] Crowther MA, Cook DJ, Meade MO, et al. Thrombocytopenia in medical-surgical critically ill patients: prevalence, incidence, and risk factors. J Crit Care 2005; 20: 348-353.

[10] Ali N, Auerbach HE. New-onset acute thrombocytopenia in hospitalized patients: pathophysiology and diagnostic approach. J Community Hosp Intern Med Perspect. 2017; 7: 157-167.

[11] McCrae K. Immune thrombocytopenia: No longer 'idiopathic'. Cleve Clin J Med. 2011; 78: 358-373.

[12] Cines DB, Blanchette VS. Immune thrombocytopenic purpura. N Engl J Med. 2002; 346: 995-1008.

[13] Neylon AJ, Saunders PW, Howard MR, et al. Clinically significant newly presenting autoimmune thrombocytopenic purpura in adults: a prospective study of a population-based cohort of 245 patients. Br J Haematol. 2003; 122: 966-974.

[14] Sarpatwari A, Bennett D, Logie JW, et al. Thromboembolic events among adult patients with primary immune thrombocytopenia in the United Kingdom General Practice Research Database. Haematologica 2010; 95: 1167-1175.

[15] Frank B, Grotta JC, Alexandrov AV, et al. Thrombolysis in stroke despite contraindications or warnings? Stroke 2013; 44: 727733.

[16] Wang TY, Ou FS, Roe MT, et al. Incidence and prognostic significance of thrombocytopenia developed during acute coronary syndrome in contemporary clinical practice. Circulation 2009; 119: 2454-2462.

[17] Bhatt DL, Hulot JS, Moliterno DJ, et al. Antiplatelet and anticoagulation therapy for acute coronary syndromes. Circ Res. 2014; 114: 1929-1943.

[18] Coven DL, Kalyanasundaram A, Shirani J. Acute coronary syndromes clinical practice guidelines. Eur Soc Cardiol. Updated: Sep 30, 2020.
[19] Yadav M, Généreux P, Giustino G, et al. Effect of baseline thrombocytopenia on ischemic outcomes in patients with acute coronary syndromes who undergo percutaneous coronary intervention. Can J Cardiol. 2016; 32: 226-233.

[20] McCarthy CP, Steg G, Bhatt DL. The management of antiplatelet therapy in acute coronary syndrome patients with thrombocytopenia: a clinical conundrum. Eur Heart J. 2017; 38: 34883492.

[21] Bhatt DL, Cryer BL, Contant CF, et al. Clopidogrel with or without omeprazole in coronary artery disease. N Engl J Med. 2010; 363: 1909-1917.

[22] Demircelik B, Altinsoy M, Bozduman F, et al. Coronary intervention for acute coronary syndrome in a 51 -year-old man with immune thrombocytopenic purpura: a case report. J Med Case Rep. 2014; 8: 214

[23] Wiviott SD, Braunwald E, McCabe CH, et al. Prasugrel versus clopidogrel in patients with acute coronary syndromes. N Engl J Med. 2007; 357: 2001-2015.

[24] Bermejo N, Sigüienza R, Ibañez F. Management of primary immune thrombocytopenia with eltrombopag in a patient with recent acute coronary syndrome. Rev Esp Cardiol. 2017; 70: $56-65$.

[25] Ruiz-Irastoza G, Crowther M, Branch W, et al. Antiphospholipid syndrome. Lancet 2010; 376: 1498-1509.

Fehér Ágnes dr., Budapest, Korányi Sándor u. 2/a, 1083 e-mail: feher.agnes@med.semmelweis-univ.hu)

\section{„Non multa, sed multum." (Plinius) (Ne sokfélét, hanem néhány valóban fontosat.)}

A cikk a Creative Commons Attribution 4.0 International License (https://creativecommons.org/licenses/by/4.0/) feltételei szerint publikált Open Access közlemény, melynek szellemében a cikk bármilyen médiumban szabadon felhasználható, megosztható és újraközölhető, feltéve, hogy az eredeti szerző és a közlés helye, illetve a CC License linkje és az esetlegesen végrehajtott módosítások feltüntetésre kerülnek. (SID_1) 